\title{
Associations between air pollution and outpatient visits for arrhythmia in Hangzhou, China
}

\author{
Mingwei Wang ${ }^{1}$, Juan Chen ${ }^{1}$, Zhi Zhang ${ }^{1}$, Ping Yu', Wentao Gan ${ }^{1}$, Zhaoming $\operatorname{Tan}^{2}$ and Junzhe Bao ${ }^{3 *}$
}

\begin{abstract}
Background: Arrhythmia is a common cardiovascular event that is associated with increased cardiovascular health risks. Previous studies that have explored the association between air pollution and arrhythmia have obtained inconsistent results, and the association between the two in China is unclear.

Methods: We collected daily data on air pollutants and meteorological factors from 1st January 2014 to 31st December 2016, along with daily outpatient visits for arrhythmia in Hangzhou, China. We used a quasi-Poisson regression along with a distributed lag nonlinear model to study the association between air pollution and arrhythmia morbidity.
\end{abstract}

Results: The results of the single-pollutant model showed that each increase of $10 \mu \mathrm{g} / \mathrm{m}^{3}$ of Fine particulate matter $\left(\mathrm{PM}_{2.5}\right)$, Coarse particulate matter $\left(\mathrm{PM}_{10}\right)$, Sulphur dioxide $\left(\mathrm{SO}_{2}\right)$, Nitrogen dioxide $\left(\mathrm{NO}_{2}\right)$, and Ozone $\left(\mathrm{O}_{3}\right)$ resulted in increases of $0.6 \%(-0.9,2.2 \%), 0.7 \%(-0.4,1.7 \%), 11.9 \%(4.5,19.9 \%), 6.7 \%(3.6,9.9 \%)$, and $-0.9 \%(-2.9,1.2 \%)$, respectively, in outpatient visits for arrhythmia; each increase of $1 \mathrm{mg} / \mathrm{m}^{3}$ increase of carbon monoxide (CO) resulted in increase of $11.3 \%(-5.9,31.6 \%)$ in arrhythmia. The short-term effects of air pollution on arrhythmia lasted 3 days, and the most harmful effects were observed on the same day that the pollution occurred. Results of the subgroup analyses showed that $\mathrm{SO}_{2}$ and $\mathrm{NO}_{2}$ affected both men and women, but differences between the sexes were not statistically significant. The effect of $\mathrm{SO}_{2}$ on the middle-aged population was statistically significant. The effect of $\mathrm{NO}_{2}$ was significant in both the young and middle-aged population, and no significant difference was found between them. Significant effects of air pollution on arrhythmia were only detected in the cold season. The results of the two-pollutants model and the single-pollutant model were similar.

Conclusions: $\mathrm{SO}_{2}$ and $\mathrm{NO}_{2}$ may induce arrhythmia, and the harmful effects are primarily observed in the cold season. There is no evidence of $\mathrm{PM}_{2.5}, \mathrm{PM}_{10}, \mathrm{CO}$ and $\mathrm{O}_{3}$ increasing arrhythmia risk. Special attention should be given to sensitive populations during the high-risk period.

Keywords: Arrhythmia, Air pollution, Time-series analysis, Season

\footnotetext{
* Correspondence: baojz@zzu.edu.cn

${ }^{3}$ College of Public Health, Zhengzhou University, Zhengzhou, China

Full list of author information is available at the end of the article
} 


\section{Background}

Cardio-cerebrovascular diseases and cancer are the main causes of death worldwide [1], and the associations between these diseases and environmental factors have been frequently reported [2,3]. According to an analysis of the burdens of disease caused by air pollution conducted by the World Health Organization (WHO), over 2 million premature deaths each year can be attributed to urban outdoor and indoor air pollution [4]. In recent years, research on the association between air pollution and cardiovascular or respiratory diseases has received increased attention, and this work has generally shown that exposure to air pollutants is closely associated with the occurrence of cardiovascular and respiratory disease [5-9].

Arrhythmia is a common cardiovascular event and is associated with increased cardiovascular health risks [10], such as cardiac arrest (or death), resulting in reduced quality of life, disability, mortality, and increased medical care costs. One review has indicated that there is a high degree of uncertainty relating to the effect of air pollution on arrhythmias [11]. Most previous studies examining the relationship between air pollution and arrhythmias have been conducted in North America and Western Europe; therefore, the results of these studies may not apply to mainland China because of differences in the characteristics of air pollution, weather, health conditions, and the susceptibility of the population. In addition, evidence from developing countries is limited. The mechanism by which air pollutants cause acute cardiac events might involve cardiac autonomic function, myocardial repolarization, local and systemic inflammation, reactive oxygen species, coagulation, and myocardial ischemia [12].

In this study, we assumed that short-term exposure to air pollutants might induce arrhythmia and used a timeseries quasi-Poisson model to study the association between the daily mean concentration of air pollutants and daily outpatient visits for arrhythmia. We aimed to identify the period of highest risk and characteristics of the sensitive population.

\section{Methods}

\section{Study area}

Hangzhou is the capital city of Zhejiang Province, an important political, economic, cultural, and financial center in eastern China $\left(30^{\circ} 16^{\prime} \mathrm{N}, 120^{\circ} 12^{\prime} \mathrm{E}\right)$ and has a typical subtropical monsoon climate. The residential population of Hangzhou reached 9 million in 2015.

\section{Air pollution and meteorological data collection}

Air pollution data were collected from the National City Air Quality Real-time Release Platform (http://106.37.2 08.233:20035/) and covered the period from 1st Jan.
2014 to 31st Dec. 2016, and the daily mean concentrations for each air pollutant were averaged for all of the 11 fixed-site air pollution monitoring stations. The meteorological data were collected from the National Meteorological Data Sharing Platform (http://data.cma.cn/) and consisted of daily mean temperature, maximum temperature, minimum temperature, mean relative humidity, mean wind speed, and atmospheric pressure.

\section{Outpatient arrhythmia data}

Outpatient arrhythmia data were collected during the same period from the arrhythmia outpatient office at the Cardiac Centre of the Affiliated Hospital of Hangzhou Normal University (acquired from the HIS system of the hospital), including date of visit, age, gender, and home address. The diagnosis of arrhythmia was made by clinicians based on ECG standards. Appointments and follow-up patients were excluded. Patients from other areas (based on their home address) were also excluded, but these represented a small fraction of patients in the data set.

\section{Statistical analyses}

A generalized linear model with a quasi-Poisson distribution was used to explore the association between air pollution and outpatient visits of patients with arrhythmia. The following covariates were included: calendar date, daily mean temperature, relative humidity, public holiday, and day-of-week. A natural cubic spline with seven degrees of freedom per year was applied to calendar time to smoothly model long-term and seasonal patterns [13]; another cubic spline with three degrees of freedom was applied to smoothly model daily mean ambient temperature (the 7-day moving average) and relative humidity [14]. Public holidays and the day-of-week were adjusted as indicator variables. We created a crossbasis matrix for air pollutants to consider their possible delayed and cumulative effects on arrhythmia, within the framework of the distributed lag-linear model [15]. The models were used to estimate the relative risks of outpatient visits for arrhythmia at various degrees of ambient air pollution: $10 \mu \mathrm{g} / \mathrm{m}^{3}$ for Fine particulate matter $\left(\mathrm{PM}_{2.5}\right)$, Coarse particulate matter $\left(\mathrm{PM}_{10}\right)$, Sulphur dioxide $\left(\mathrm{SO}_{2}\right)$, Nitrogen dioxide $\left(\mathrm{NO}_{2}\right)$, Ozone $\left(\mathrm{O}_{3}\right)$; and 1 $\mathrm{mg} / \mathrm{m}^{3}$ for carbon monoxide (CO).

Subgroup analyses were performed to identify populations sensitive to air pollution by calculating the relative risk of cardiac arrhythmia caused by air pollution in each subgroup. The warm season ran from May to October, and the cold season ran from November to April. We used the Cochran $\mathrm{Q}$ test to test for differences between subpopulations.

Sensitivity analyses were performed by changing $\mathrm{df}$ values for the time trend and relative humidity, as well 
as the lag days of air pollution in the model. All statistical analyses were computed using $\mathrm{R}$ software (version 3.4.0) with the "dlnm" package (version 2.3.2) to create distributed lag linear models. Two-tailed $p$-values $<0.05$ were considered statistically significant.

\section{Results}

A total of 16,191 cases of arrhythmia outpatients were included in this study, with female patients accounting for a slightly higher number of cases than males. Most patients were aged between 45 and 60 years old, and the number of visits in the hot season (May-October) was slightly greater than in the cold season (NovemberApril) (Table 1).

The mean daily concentration (standard deviation, SD) of $\mathrm{PM}_{2.5}, \mathrm{PM}_{10}, \mathrm{SO}_{2}, \mathrm{NO}_{2}, \mathrm{CO}$, and $\mathrm{O}_{3}$ were 52.9 (29.2) $\mu \mathrm{g} / \mathrm{m}^{3}, 77.6(41.8) \mu \mathrm{g} / \mathrm{m}^{3}, 15.5(7.7) \mu \mathrm{g} / \mathrm{m}^{3}, 43.9(16.5)$ $\mu \mathrm{g} / \mathrm{m}^{3}, \quad 0.85 \quad(0.25) \mathrm{mg} / \mathrm{m}^{3}$ and 55.1 (27.1) $\mu \mathrm{g} / \mathrm{m}^{3}$, respectively. The average daily readings (SD) of air temperature, relative humidity, air pressure, and wind speed were $17.8(8.4){ }^{\circ} \mathrm{C}$, 74.4 (13.9) \%, 1011.4 (8.9) hPa, and $3.9(3.8) \mathrm{m} / \mathrm{s}$, respectively (Table 2 ).

We have examined the shape of the exposure-response relationships using natural spline functions and found them to be generally linear (Additional file 1). Therefore, generalized linear model with linear function was adopted. Table 3 showed that each increase of $10 \mu \mathrm{g} / \mathrm{m}^{3}$ in the concentration of atmospheric $\mathrm{PM}_{2.5}, \mathrm{PM}_{10}, \mathrm{SO}_{2}$, $\mathrm{NO}_{2}$, and $\mathrm{O}_{3}$ led to an increase in the number of arrhythmia outpatients (Lag of $0-3 \mathrm{~d}$ ), with relative risks (RRs, 95\% CI) of 1.006 (0.991, 1.022), 1.007 (0.996, 1.0017), 1.119 (1.045, 1.199), 1.067 (1.036, 1.099), and $0.991(0.971,1.012)$, respectively. The RR for a $1 \mathrm{mg} / \mathrm{m}^{3}$ increase in $\mathrm{CO}$ was $1.113(0.941,1.316)$. The effects of $\mathrm{SO}_{2}$ and $\mathrm{NO}_{2}$ were statistically significant, and the most harmful effect was observed on the same day that the pollution occurred. For each increment in the interquartile range of each pollutant, the RRs $(95 \% \mathrm{CI})$ were 1.025

Table 1 Demographic and seasonal characteristics of outpatient visits for arrhythmia

\begin{tabular}{|c|c|c|}
\hline Variables & Number of Patients & Percentage (\%) \\
\hline \multicolumn{3}{|l|}{ Gender Groups } \\
\hline Male & 7206 & 44.5 \\
\hline Female & 8985 & 55.5 \\
\hline \multicolumn{3}{|l|}{ Age Groups } \\
\hline$<45$ & 3701 & 22.9 \\
\hline $45-60$ & 7368 & 45.5 \\
\hline$\geq 60$ & 5122 & 31.6 \\
\hline \multicolumn{3}{|l|}{ Season Groups } \\
\hline Warm season & 8152 & 50.3 \\
\hline Cold Season & 8039 & 49.7 \\
\hline
\end{tabular}

Table 2 Distributions of daily air pollution, meteorological factors, and outpatient visits for arrhythmia

\begin{tabular}{lllllll}
\hline Variables & Mean + SD & Min & 25th & 50th & 75th & Max \\
\hline $\mathrm{PM}_{2.5}\left(\mathrm{ug} / \mathrm{m}^{3}\right)$ & $52.9+29.2$ & 7.6 & 31.2 & 46.6 & 67.7 & 205.5 \\
$\mathrm{PM}_{10}\left(\mathrm{ug} / \mathrm{m}^{3}\right)$ & $77.6+41.8$ & 5.8 & 46.6 & 70.5 & 101.0 & 271.0 \\
$\mathrm{SO}_{2}\left(\mathrm{ug} / \mathrm{m}^{3}\right)$ & $15.5+7.7$ & 4.1 & 9.7 & 13.5 & 19.1 & 46.7 \\
$\mathrm{NO}_{2}\left(\mathrm{ug} / \mathrm{m}^{3}\right)$ & $43.9+16.5$ & 9.3 & 31.5 & 41.8 & 54.4 & 109.7 \\
$\mathrm{CO}\left(\mathrm{mg} / \mathrm{m}^{3}\right)$ & $0.85+0.25$ & 0.39 & 0.67 & 0.80 & 0.97 & 2.05 \\
$\mathrm{O}_{3}\left(\mathrm{ug} / \mathrm{m}^{3}\right)$ & $55.1+27.1$ & 5.3 & 34.2 & 51.8 & 73.5 & 149.3 \\
Temperature $\left({ }^{\circ} \mathrm{C}\right)$ & $17.8+8.4$ & -5.0 & 10.5 & 19.1 & 24.4 & 34.4 \\
Humidity $(\%)$ & $74.4+13.9$ & 27.0 & 65.0 & 76.0 & 85.0 & 98.0 \\
Air pressure $(\mathrm{hPa})$ & $1011.4+8.9$ & 989.3 & 1003.7 & 1011.1 & 1018.7 & 1036.6 \\
Wind Speed $(\mathrm{m} / \mathrm{s})$ & $3.9+3.8$ & 0.0 & 0.5 & 3.2 & 7.4 & 12.7 \\
Outpatient visits & $14.8+7.9$ & 0.0 & 9.0 & 14.0 & 20.0 & 59.0 \\
\hline
\end{tabular}

(0.970, 1.083), 1.038 (0.978, 1.100), $1.116(1.041,1.188)$, $1.160(1.079,1.303), 1.032(0.982,1.086)$, and 0.966 $(0.889,1.049)$ for $\mathrm{PM}_{2.5}\left(36.50 \mu \mathrm{g} / \mathrm{m}^{3}\right), \mathrm{PM}_{10}(54.39 \mu \mathrm{g} /$ $\left.\mathrm{m}^{3}\right), \mathrm{SO}_{2}\left(9.41 \mu \mathrm{g} / \mathrm{m}^{3}\right), \mathrm{NO}_{2}\left(22.93 \mu \mathrm{g} / \mathrm{m}^{3}\right), \mathrm{CO}(0.30 \mathrm{mg} /$ $\left.\mathrm{m}^{3}\right)$, and $\mathrm{O}_{3}\left(39.26 \mu \mathrm{g} / \mathrm{m}^{3}\right)$, respectively.

The subgroup analyses showed that $\mathrm{SO}_{2}$ and $\mathrm{NO}_{2}$ affected both male and female patients, and there was no significant difference in their effects. The effect of $\mathrm{SO}_{2}$ was statistically significant in the middle-aged group, and the effect of $\mathrm{NO}_{2}$ was statistically significant in both the younger age and the middle-aged groups, while the difference between them was not statistically significant. The effect of air pollution on arrhythmia was only statistically significant in the cold season (Table 4). The results of the two-pollutant model and the singlepollutant models were similar (Table 5).

The sensitivity analyses showed that the relative risk for cardiac arrhythmia was generally similar for various degrees of freedom for the time trend (5-9 df/year), humidity $(2-5 \mathrm{df})$, as well as for various lag times (2-14 days) (Additional file 2, Additional file 3). This finding confirmed the robustness of our results.

\section{Discussion}

We found that $\mathrm{SO}_{2}$ and $\mathrm{NO}_{2}$ had significant effects on arrhythmia outpatient visits in Hangzhou. A previous meta-analysis has revealed significant associations between arrhythmia hospitalization or arrhythmia mortality and $\mathrm{PM}_{2.5}, \mathrm{PM}_{10}, \mathrm{SO}_{2}$, and $\mathrm{NO}_{2}$, after synthesizing the results of 23 studies. Furthermore, these associations were stronger in Asia compared with those that have been documented for Europe and North America. Most of the studies included in this meta-analysis were conducted in developed countries, with only one conducted in China, and this study had not considered the lag effect [16]. Link et al. also found a positive association between short-term $\mathrm{PM}_{2.5}$ exposure and atrial fibrillation 
Table 3 Distributions of relative risks for arrhythmia caused by six air pollutants on lags of different lengths (in days) ${ }^{a}$

\begin{tabular}{|c|c|c|c|c|c|c|}
\hline Lag & $\mathrm{PM}_{2.5}$ & $\mathrm{PM}_{10}$ & $\mathrm{SO}_{2}$ & $\mathrm{NO}_{2}$ & $\mathrm{CO}$ & $\mathrm{O}_{3}$ \\
\hline 0 & 1.009 (0.998-1.020) & $1.003(0.995-1.011)$ & $1.045(0.997-1.095)$ & 1.023 (0.999-1.047) & $\begin{array}{l}1.084 \\
(0.943,1.246)\end{array}$ & $\begin{array}{l}0.997 \\
(0.979,1.015)\end{array}$ \\
\hline 1 & 0.996 (0.984-1.008) & $1.001(0.993-1.010)$ & $1.030(0.986-1.076)$ & 1.023 (0.999-1.048) & $\begin{array}{l}1.031 \\
(0.890,1.196)\end{array}$ & $\begin{array}{l}0.999 \\
(0.983,1.015)\end{array}$ \\
\hline 2 & $1.006(0.994-1.018)$ & $1.004(0.996-1.013)$ & $1.030(0.987-1.075)$ & $1.007(0.999-1.030)$ & $\begin{array}{l}1.023 \\
(0.886,1.826)\end{array}$ & $\begin{array}{l}0.996 \\
(0.981,1.012)\end{array}$ \\
\hline 3 & $0.994(0.984-1.005)$ & $0.997(0.989-1.004)$ & 1.009 (0.969-1.051) & $1.012(0.992-1.033)$ & $\begin{array}{l}0.919 \\
(0.804,1.049)\end{array}$ & $\begin{array}{l}0.993 \\
(0.980,1.007)\end{array}$ \\
\hline $0-3$ & $1.006(0.991-1.022)$ & 1.007 (0.996-1.017) & 1.119 (1.045-1.199) & $1.067(1.036-1.099)$ & $\begin{array}{l}1.113 \\
(0.941,1.316)\end{array}$ & $\begin{array}{l}0.991 \\
(0.971,1.012)\end{array}$ \\
\hline
\end{tabular}

${ }^{a}$ For $\mathrm{PM}_{2.5}, \mathrm{PM}_{10}, \mathrm{SO}_{2}, \mathrm{NO}_{2}$, and $\mathrm{O}_{3}$, the relative risks were associated with increments of $10 \mu \mathrm{g} / \mathrm{m}^{3}$; for $\mathrm{CO}$, the increment was $1 \mathrm{mg} / \mathrm{m}^{3}$

[17] by utilizing a case-crossover analysis of 176 patients. However, a time-series study of nearly 400,000 emergency department visitors from seven Canadian cities found that there was no significant association between air pollution and arrhythmia [18]. Bunch et al. also found no significant association between atrial fibrillation hospitalization and $\mathrm{PM}_{2.5}$ [19]. We found that increased concentrations of $\mathrm{PM}_{2.5}$ and $\mathrm{PM}_{10}$ might increase the risk of arrhythmia, but the effects were not statistically significant. This lack of significance may stem from the small sample size and the limited number of years that were sampled in this study.

Our study revealed that air pollution affects both sexes and primarily affects the middle-aged population; however, there were no statistically significant differences between sexes and age groups. Zhao et al. also found that air pollution affected both males and females, with a more pronounced deleterious effect on females [20]. A study in Shanghai found that elderly patients with arrhythmia were more sensitive to air pollution [20], while a meta-analysis involving 25 studies found that the health effects of air pollution on elderly patients were not any greater than their effects on the general population [16]. The physical condition of the middle-aged population is generally better than that of the elderly. However, middle-aged patients are often actively working and experience more stress; in contrast, elderly patients are often retired and are thus not working under as stressful conditions. Consequently, when the air pollution is severe, elderly patients have the option of

Table 4 Distributions of the relative risks for arrhythmia at various levels of air pollutants in different subgroups and seasons ${ }^{\text {a }}$

\begin{tabular}{|c|c|c|c|c|c|c|}
\hline Variables & $\mathrm{PM}_{2.5}$ & $\mathrm{PM}_{10}$ & $\mathrm{SO}_{2}$ & $\mathrm{NO}_{2}$ & $\mathrm{CO}$ & $\mathrm{O}_{3}$ \\
\hline Overall & $\begin{array}{l}1.007 \\
(0.992,1.022)\end{array}$ & $\begin{array}{l}1.007 \\
(0.997,1.018)\end{array}$ & $\begin{array}{l}1.119 \\
(1.045,1.199)\end{array}$ & $\begin{array}{l}1.067 \\
(1.037,1.099)\end{array}$ & $\begin{array}{l}1.113 \\
(0.941,1.316)\end{array}$ & $\begin{array}{l}0.991 \\
(0.971,1.012)\end{array}$ \\
\hline \multicolumn{7}{|l|}{ Gender } \\
\hline Male & $\begin{array}{l}1.018 \\
(0.999,1.037)\end{array}$ & $\begin{array}{l}1.009 \\
(0.996,1.023)\end{array}$ & $\begin{array}{l}1.112 \\
(1.028,1.201)\end{array}$ & $\begin{array}{l}1.071 \\
(1.032,1.112)\end{array}$ & $\begin{array}{l}1.251 \\
(1.013,1.546)\end{array}$ & $\begin{array}{l}0.989 \\
(0.963,1.016)\end{array}$ \\
\hline Female & $\begin{array}{l}0.997 \\
(0.979,1.016)\end{array}$ & $\begin{array}{l}1.006 \\
(0.993,1.018)\end{array}$ & $\begin{array}{l}1.137 \\
(1.032,1.210)\end{array}$ & $\begin{array}{l}1.064 \\
(1.027,1.102)\end{array}$ & $\begin{array}{l}1.011 \\
(0.824,1.239)\end{array}$ & $\begin{array}{l}0.993 \\
(0.968,1.018)\end{array}$ \\
\hline \multicolumn{7}{|l|}{ Age } \\
\hline$<45$ & $\begin{array}{l}1.018 \\
(0.990,1.048)\end{array}$ & $\begin{array}{l}1.013 \\
(0.993,1.033)\end{array}$ & $\begin{array}{l}1.105 \\
(0.973,1.255)\end{array}$ & $\begin{array}{l}1.109 \\
(1.050,1.171)\end{array}$ & $\begin{array}{l}1.052 \\
(0.763,1.450)\end{array}$ & $\begin{array}{l}0.989 \\
(0.954,1.027)\end{array}$ \\
\hline $45-60$ & $\begin{array}{l}1.007 \\
(0.988,1.026)\end{array}$ & $\begin{array}{l}1.010 \\
(0.997,1.023)\end{array}$ & $\begin{array}{l}1.154 \\
(1.062,1.255)\end{array}$ & $\begin{array}{l}1.076 \\
(1.038,1.116)\end{array}$ & $\begin{array}{l}1.184 \\
(0.962,1.457)\end{array}$ & $\begin{array}{l}0.984 \\
(0.958,1.010)\end{array}$ \\
\hline$\geq 60$ & $\begin{array}{l}0.995 \\
(0.972,1.019)\end{array}$ & $\begin{array}{l}0.998 \\
(0.982,1.014)\end{array}$ & $\begin{array}{l}1.077 \\
(0.963,1.204)\end{array}$ & $\begin{array}{l}1.027 \\
(0.981,1.076)\end{array}$ & $\begin{array}{l}1.013 \\
(0.781,1.313)\end{array}$ & $\begin{array}{l}1.004 \\
(0.970,1.038)\end{array}$ \\
\hline \multicolumn{7}{|l|}{ Season } \\
\hline Warm & $\begin{array}{l}0.989 \\
(0.963,1.015)\end{array}$ & $\begin{array}{l}0.994 \\
(0.977,1.011)\end{array}$ & $\begin{array}{l}1.052 \\
(0.924,1.195)\end{array}$ & $\begin{array}{l}0.995 \\
(0.944,1.048)\end{array}$ & $\begin{array}{l}0.944 \\
(0.698,1.276)\end{array}$ & $\begin{array}{l}0.997 \\
(0 . .962,1.033)\end{array}$ \\
\hline Cold & $\begin{array}{l}1.016 \\
(0.997,1.033)\end{array}$ & $\begin{array}{l}1.013 \\
(0.999,1.026)\end{array}$ & $\begin{array}{l}1.122 \\
(1.034,1.223)\end{array}$ & $\begin{array}{l}1.075 \\
(1.033,1.119)\end{array}$ & $\begin{array}{l}1.142 \\
(0.903,1.443)\end{array}$ & $\begin{array}{l}0.982 \\
(0.925,1.042)\end{array}$ \\
\hline
\end{tabular}

${ }^{\mathrm{a}}$ For $\mathrm{PM}_{2.5}, \mathrm{PM}_{10}, \mathrm{SO}_{2}, \mathrm{NO}_{2}$, and $\mathrm{O}_{3}$, the relative risks were associated with increments of $10 \mu \mathrm{g} / \mathrm{m}^{3}$; for CO the increment was $1 \mathrm{mg} / \mathrm{m}^{3}$. A Cochran Q test was used to test for differences between subpopulations, and no statistically significant differences were found between subpopulations 
Table 5 Results of the two-pollutant model

\begin{tabular}{lllllll}
\hline Controlled Pollutant & $\mathbf{P M}_{2.5}$ & $\mathbf{P M}_{\mathbf{1 0}}$ & $\mathbf{S O}_{\mathbf{2}}$ & $\mathbf{N O}_{\mathbf{2}}$ & $\mathbf{C O}$ & $\mathbf{O}_{\mathbf{3}}$ \\
\hline None & $1.007(0.992,1.022)$ & $1.007(0.997,1.018)$ & $1.119(1.045,1.199)$ & $1.067(1.037,1.099)$ & $1.113(0.941,1.316)$ & $0.991(0.971,1.012)$ \\
$\mathrm{PM}_{2.5}$ & $/$ & $1.002(0.984,1.019)$ & $1.125(1.051,1.203)$ & $1.079(1.042,1.116)$ & $1.076(0.862,1.345)$ & $0.990(0.969,1.011)$ \\
$\mathrm{PM}_{10}$ & $1.008(0.984,1.032)$ & $/$ & $1.131(1.056,1.219)$ & $1.086(1.048,1.124)$ & $1.093(0.984,1.338)$ & $0.991(0.970,1.012)$ \\
$\mathrm{SO}_{2}$ & $0.999(0.984,1.016)$ & $1.001(0.989,1.013)$ & $/$ & $1.061(1.027,1.096)$ & $1.068(0.880,1.317)$ & $0.990(0.969,1.011)$ \\
$\mathrm{NO}_{2}$ & $0.996(0.979,1.012)$ & $0.997(0.985,1.009)$ & $1.084(1.009,1.164)$ & $/$ & $1.031(0.825,1.297)$ & $0.992(0.971,1.013)$ \\
$\mathrm{CO}$ & $1.003(0.985,1.022)$ & $1.004(0.992,1.016)$ & $1.125(1.057,1.198)$ & $1.066(1.034,1.098)$ & $/$ & $0.992(0.971,1.013)$ \\
$\mathrm{O}_{3}$ & $1.009(0.994,1.025)$ & $1.008(0.998,1.019)$ & $1.130(1.061,1.200)$ & $1.061(1.031,1.089)$ & $1.120(0.946,1.323)$ & $/$ \\
\hline
\end{tabular}

simply not leaving their homes. These factors may explain why middle-aged patients are susceptible to air pollution. Because of the small sample size and the limited number of years that were examined, the lack of a significant association between air pollution and arrhythmia in elderly patients requires additional research.

Our study found that the harmful effect of air pollution on arrhythmia primarily occurred in the cold season. Santurtún et al. also found that the effect of $\mathrm{NO}_{2}$ on arrhythmia primarily occurred in the winter [21]. In contrast, Zhao et al. found a stronger association between $\mathrm{NO}_{2}, \mathrm{SO}_{2}$, and cardiac arrhythmias in the warm season [20]. The reasons underlying the greater harmful effects of air pollution in the cold season may be that the concentration of air pollutants, and thus the potential for damage, is higher in the cold season; that the combined effects of low temperature and air pollution.

One of the possible pathways connecting short-term exposure to air pollution and cardiovascular events could be autonomic nervous system dysfunction [22]; however, toxicological studies in animals and clinical studies in humans are needed to verify this hypothesis. Air pollutants have also been found to be associated with increased systemic inflammation, increased platelet activation, and decreased erythrocyte antioxidant enzyme activity; all of these factors may induce arrhythmias [21].

We found that there were no statistically significant differences between the effects of air pollution in different subgroups. This may be due to the fact that the difference between different subgroups is only caused by sampling error; or it may be that the number of samples involved in this study is not enough, and the significance of the difference has not been detected. These contents need further study in the future.

There are several limitations of this study requiring consideration. First, given that this was an ecological study, ecological inaccuracies may exist. The air pollution and meteorological data were obtained from several monitoring stations instead of individual exposure measurements; therefore, the exposure assessment in this study might be inaccurate. Second, given the limitations of data acquisition, socioeconomic factors were not considered in this study; in addition, outpatients could not be classified into disease subtypes, which could only be classified for inpatients, according to the World Health Organization's International Classification of Diseases, the 10th version (ICD-10). Third, this study was conducted in a single city (Hangzhou); thus, our findings cannot be generalized to other cities with different environmental and economic characteristics. Cohort studies are needed to assess the long-term effects of air pollution on arrhythmias.

\section{Conclusions}

$\mathrm{SO}_{2}$ and $\mathrm{NO}_{2}$ may induce arrhythmia, and the harmful effects are primarily observed in the cold season. Air pollution affects both males and females, and the middle-aged population is especially sensitive to air pollution. The government should take action to reduce air pollution and make special interventions for sensitive individuals during the cold season.

\section{Supplementary information}

Supplementary information accompanies this paper at https://doi.org/10. 1186/s12889-020-09628-y.

Additional file 1: The exposure-response relationships between air pollutants and arrhythmia using natural spline functions.

Additional file 2: The change of relative risk for arrhythmia caused by $\mathrm{NO}_{2}$ in various degrees of freedom.

Additional file 3: The change of relative risk for arrhythmia caused by $\mathrm{NO}_{2}$ in various lag time.

\section{Abbreviations}

$\mathrm{PM}_{25}$ : Fine particulate matter; $\mathrm{PM}_{10}$ : Coarse particulate matter; $\mathrm{SO}_{2}$ : Sulphur dioxide; $\mathrm{NO}_{2}$ : Nitrogen dioxide; $\mathrm{CO}$ : Carbon monoxide; $\mathrm{O}_{3}$ : Ozone; WHO: World Health Organization; ICD-10: International Classification of Diseases, the 10th version; SD: Standard deviation, SD; RR: Relative risk; $\mathrm{Cl}$ : Confidence interval

\section{Acknowledgements}

Not applicable.

\section{Authors' contributions}

JZB and MWW conceived of the study. MWW analyzed the data and drafted the manuscript. JC, ZZ, PY, WTG and ZMT helped in the acquisition and 
analysis of data, as well as the discussion of the results. JZB reviewed the manuscript for important intellectual content. All authors read and approved the final manuscript.

\section{Funding}

This study was supported by Hangzhou science and technology project (Grant No. 20150733Q24; 20171334 M01; 20191203B96; 20191203B105), China Postdoctoral Science Foundation (Grant No. 2017 M612827), as well as Zhejiang Kang Enbei Hospital Management Soft Science Project (2017ZHAKEB318). The funders had no role in the study design, data collection and analysis, decision to publish, or preparation of the manuscript.

\section{Availability of data and materials}

Due to confidentiality requirements, the data involved in this study is currently not publicly available.

\section{Ethics approval and consent to participate}

All procedures in this study had been approved by the Ethics Committee of the Affiliated Hospital of Hangzhou Normal University.

\section{Consent for publication}

Not applicable.

\section{Competing interests}

The authors declare no conflict of interest.

\section{Author details}

'Department of Cardiology, the Affiliated Hospital of Hangzhou Normal University, Hangzhou, China. ${ }^{2}$ Nanjing Municipal Human Resources and Social Security Bureau, Nanjing, China. ${ }^{3}$ College of Public Health, Zhengzhou University, Zhengzhou, China.

Received: 27 June 2020 Accepted: 29 September 2020

Published online: 08 October 2020

\section{References}

1. Lozano R, Naghavi M, Foreman K, Lim S, Shibuya K, Aboyans V, Abraham J, Adair T, Aggarwal R, Ahn SY, et al. Global and regional mortality from 235 causes of death for 20 age groups in 1990 and 2010: a systematic analysis for the global burden of disease study 2010. Lancet. 2012 380(9859):2095-128.

2. Danaei G, Vander Hoorn S, Lopez AD, Murray CJ, Ezzati M. Comparative risk assessment collaborating $\mathrm{g}$ : causes of cancer in the world: comparative risk assessment of nine behavioural and environmental risk factors. Lancet. 2005 366(9499):1784-93.

3. Mustafic H, Jabre P, Caussin C, Murad MH, Escolano S, Tafflet M, Perier MC, Marijon E, Vernerey D, Empana JP, et al. Main air pollutants and myocardial infarction: a systematic review and meta-analysis. JAMA. 2012;307(7):713-21.

4. WHO: Air quality guidelines - global update 2005. https://www.who.int/phe/ health topics/outdoorair/outdoorair aqg/en/.

5. Zhou M, Wang H, Zhu J, Chen W, Wang L, Liu S, Li Y, Wang L, Liu Y, Yin P, et al. Cause-specific mortality for 240 causes in China during 1990-2013: a systematic subnational analysis for the global burden of disease study 2013. Lancet. 2016;387(10015):251-72.

6. Knibbs LD, Cortes de Waterman AM, Toelle BG, Guo Y, Denison L, Jalaludin B, Marks GB, Williams GM. The Australian child health and air pollution study (ACHAPS): a national population-based cross-sectional study of long-term exposure to outdoor air pollution, asthma, and lung function. Environ Int. 2018:120:394-403.

7. Rodriguez-Villamizar LA, Rojas-Roa NY, Blanco-Becerra LC, Herrera-Galindo VM, Fernandez-Nino JA. Short-Term Effects of Air Pollution on Respiratory and Circulatory Morbidity in Colombia 2011(-)2014: A Multi-City, TimeSeries Analysis. Int J Environ Res Public Health. 2018;15(8):1610.

8. Nhung NTT, Schindler C, Dien TM, Probst-Hensch N, Perez L, Kunzli N. Acute effects of ambient air pollution on lower respiratory infections in Hanoi children: an eight-year time series study. Environ Int. 2018;110:139-48.

9. Zhong P, Huang S, Zhang X, Wu S, Zhu Y, Li Y, Ma L. Individual-level modifiers of the acute effects of air pollution on mortality in Wuhan, China. Glob Health Res Policy. 2018;3:27.

10. Murakoshi N, Aonuma K. Epidemiology of arrhythmias and sudden cardiac death in Asia. Circ J. 2013;77(10):2419-31.
11. Watkins A, Danilewitz M, Kusha M, Masse S, Urch B, Quadros K, Spears D, Farid T, Nanthakumar K. Air pollution and arrhythmic risk: the smog is yet to clear. Can J Cardiol. 2013;29(6):734-41.

12. Brook RD, Franklin B, Cascio W, Hong Y, Howard G, Lipsett M, Luepker R, Mittleman M, Samet J, Smith SC Jr, et al. Air pollution and cardiovascular disease: a statement for healthcare professionals from the expert panel on population and prevention science of the American Heart Association. Circulation. 2004;109(21):2655-71.

13. Dominici F, Samet JM, Zeger SL. Combining evidence on air pollution and daily mortality from the 20 largest US cities: a hierarchical modelling strategy. J Roy Stat Soc. 2000;163(3):263-302.

14. Chen R, Chu C, Tan J, Cao J, Song W, Xu X, Jiang C, Ma W, Yang C, Chen B, et al. Ambient air pollution and hospital admission in Shanghai, China. J Hazard Mater. 2010;181(1-3):234-40.

15. Gasparrini A. Distributed lag linear and non-linear models in R: the package dlnm. J Stat Softw. 2011;43(8):1-20.

16. Song X, Liu Y, Hu Y, Zhao X, Tian J, Ding G, Wang S. Short-Term Exposure to Air Pollution and Cardiac Arrhythmia: A Meta-Analysis and Systematic Review. Int J Environ Res Public Health. 2016;13(7):642.

17. Link MS, Luttmann-Gibson H, Schwartz J, Mittleman MA, Wessler B, Gold DR, Dockery DW, Laden F. Acute exposure to air pollution triggers atrial fibrillation. J Am Coll Cardiol. 2013:62(9):816-25.

18. Stieb DM, Szyszkowicz M, Rowe BH, Leech JA. Air pollution and emergency department visits for cardiac and respiratory conditions: a multi-city timeseries analysis. Environ Health. 2009;8:25.

19. Bunch TJ, Horne BD, Asirvatham SJ, Day JD, Crandall BG, Weiss JP, Osborn $J \mathrm{~J}$, Anderson JL, Muhlestein JB, Lappe DL, et al. Atrial fibrillation hospitalization is not increased with short-term elevations in exposure to fine particulate air pollution. Pacing Clin Electrophysiol. 2011;34(11):1475-9.

20. Zhao A, Chen R, Kuang X, Kan H. Ambient air pollution and daily outpatient visits for cardiac arrhythmia in Shanghai, China. J Epidemiol. 2014;24(4):321-6.

21. Santurtun A, Sanchez-Lorenzo A, Villar A, Riancho JA, Zarrabeitia MT. The influence of nitrogen dioxide on arrhythmias in Spain and its relationship with atmospheric circulation. Cardiovasc Toxicol. 2017;17(1):88-96.

22. Buteau S, Goldberg MS. A structured review of panel studies used to investigate associations between ambient air pollution and heart rate variability. Environ Res. 2016;148:207-47.

\section{Publisher's Note}

Springer Nature remains neutral with regard to jurisdictional claims in published maps and institutional affiliations.

Ready to submit your research? Choose BMC and benefit from:

- fast, convenient online submission

- thorough peer review by experienced researchers in your field

- rapid publication on acceptance

- support for research data, including large and complex data types

- gold Open Access which fosters wider collaboration and increased citations

- maximum visibility for your research: over $100 \mathrm{M}$ website views per year

At $\mathrm{BMC}$, research is always in progress.

Learn more biomedcentral.com/submissions 